\title{
THE COMPOSER AND THE PUBLIC INTEREST- REGULATION OF PERFORMING RIGHT SOCIETIES
}

\author{
Herman Finkelstein*
}

INTRODUCTION

It is impossible to consider the basis for regulating performing right societies without analyzing the economic role of music in modern society. Performing right societies deal in only one phase of music-the licensing of users to perform musical works publicly for profit.

A proper understanding of our subject requires a study of the public interest involved in (a) protecting writers and publishers of copyrighted musical works; (b) permitting commercial users of those works to have ready access to them upon reasonable terms; and (c) preserving the free flow of music from the composer to the public without undue interference on the part of users acting collectively.

The economic status of the composer and the people with whom he deals must be within the scope of our inquiry. If we regulate writers and publishers when they act collectively in bargaining with commercial users, shall we also regulate the latter when they bargain collectively with performing right societies? ${ }^{1}$

Finally, if regulation appears to be necessary, should it be by judicial pronouncement in antitrust suits, or by statute? If the latter, what provisions should such statutes make in the interest of all branches of the public?

The first part of this paper will deal with the role of the composer and his publisher in modern society; the second part will discuss the subject of regulation of performing right societies in relation to the public interest.

I

The Place of the Composer in Modern Soctety

A. Difficulties Arising Out of Public Apathy Toward Theft of Literary and Musical Property

The notion that a composer or author has a property interest in his compositions is of relatively recent origin. In fact, some text writers still insist that a copyright is not property but rather is merely a personal right like the right of privacy, or the right not to be defamed. ${ }^{2}$ If gentlemen learned in the law refuse to recognize that an author is creating a property right when he toils to fashion literary or musical works, we can hardly blame the average citizen if he becomes incensed at the notion

\footnotetext{
- General Attorney, American Society of Composers, Authors and Publishers (ASCAP). The views expressed in this paper are not to be regarded as the views of ASCAP.

${ }^{1}$ For a discussion of the dangers of collective control of the media through which ideas or entertainment are disseminated, see Weaver and Cooley, Competition in the Broadcasting of Ideas and Entertainment-Shall Radio Take Over Television?, roI U. of PA. L. Rev. 72I (1953).

${ }^{2}$ For a criticism of this view see Finkelstein, Review, 48 YALE L. J. 712, 713 (1939).
} 
that he is a thief if he appropriates, or takes liberties with, a mere song. Until recent times, who ever heard of a song being worth anything? Are we not all familiar with the value placed upon the poet's output by the use of the expression, "he got it for a song," to indicate a trifling payment?

In Paull's Literary Ethics, we are told that as recently as 1832 , an owner of several theatres testified before a select committee that in his opinion no dramatist except Sheridan Knowles deserved to be paid. ${ }^{3}$ The composer of musical works was still suffering from that public attitude as late as 1918 , when Atkin, L. J., remarked:4

One has to remember that there are a great many persons honourable in every transaction of life who do have very loose notions as to the honesty of dealing with other persons' property in such matters as copyright, and I am not the first person to talk about piracy or stealing in respect of infringements of copyright. One is not likely to forget the petition of the great writer Carlyle to the House of Commons in which he sought for protection for what he called his "small winnings" for a period, I think he asked of sixty years and in which he concluded: "After such period, unless your Honourable House otherwise provides, they may begin to steal," and I certainly think that it is satisfactory to find that this Society which, after all, in the present case is merely engaged in securing the fruits of their labours to the musical composers, has a legal object and cannot be defeated in what one cannot help feeling is a position of public interest.

As a result of public indifference to the theft of literary and musical works, authors must apprehend pirates at their own expense, for the police officers in the United States do not consider the theft of property rights of authors in the same class as larceny or assault.

The opportunities for piracy of the works of authors increase with new inventions of means of mass communication. Whereas originally literary theft became profitable only through printed reproductions of the stolen work, today such piracy may be accomplished by phonograph records, tape recordings, radio, television, and other means of communicating the work publicly for profit. Infringements by means of public performances are ephemeral, and cannot be detected unless an effective policing organization is equipped to detect thousands of simultaneous performances throughout the forty-eight states.

Works of authors form the backbone of the industrial empires dependent upon these new methods of mass communication. The public interest in those who write and those who use their works is becoming greater with each new device through which the expression of an idea or emotion is communicated to vast numbers of people.

\section{B. The Users of Music}

Before the dawn of the twentieth century, composers and their publishers depended for their livelihood upon sales of sheet music. The average person was an

\footnotetext{
${ }^{3}$ Harry M. Pault, Literary Ethics 77 (1929). Copyright in America did not protect a dramatist against infringing stage performances until 1856 . (II STAT. 138.)

* Performing Rights Society v. Thompson (xgI8), quoted in C. F. James, The Stony of the PerFoRMing Right Society 27 (I95x), opinion digested in 34 T. L. R. 35 I (1918).
} 
active participant in musical entertainment through singing or playing a musical instrument. Each family had its supply of sheet music-and usually a piano-just as practically every family today has at least one radio set. At the present rate of development, television will soon be as widespread as radio.

Because radio and television broadcasters have become the greatest users of music in the field of public performance, we shall devote some time to the economics of the broadcasting industry. Others who derive profits from the use of music in public performances are hotels, taverns, restaurants, dancehall or ballroom operators, theatres, so-called wired music enterprises, symphony orchestras, and industrial users such as banks, stores, and factories. ${ }^{5}$

In order to appreciate the public interest that compels writers and publishers of copyrighted music to deal with these users through performing right societies, it is necessary to understand (a) just what performing rights are; (b) the part they play in the complex maze of the modern entertainment field; and (c) the function of the performing right society in making available these rights to commercial users of music.

\section{The Right of Public Performance for Profit}

The Copyright Act of Igog, which is still the basic copyright law today, defines the various rights granted to copyright owners. Among the exclusive rights in musical works are (a) the right to print and sell copies of the work; (b) the right to make new arrangements or adaptations of the work; (c) the right to have it recorded for mechanical or electrical reproduction; and (d) the right to perform the work publicly for profit. Each of these rights is separate and distinct from the other. Thus the purchase of a copy of sheet music does not give the buyer the right to re-arrange the work, to strike off new copies, to record it, or to perform it publicly for profit. Each of those rights must be specifically acquired.

Performing rights in musical compositions were recognized for the first time by the Copyright Act of $1897 .^{\circ}$ Although this right was maintained when the Act of I909 was passed, a limitation was imposed: whereas the I897 Act protected the copyrighted work against all public performances, the Igog Act limited such protection to performances that were both public and for profit. ${ }^{7}$

Juke box operators are also large scale users, but they claim exemption from any obligation to pay copyright royalties under the Ig09 Copyright Law (I7 U. S. C. $\$ I(e)$ ) which provides in part: "The reproduction or rendition of a musical composition by or upon coin-operated machines shall not be deemed a public performance for profit unless a fee is charged for admission to the place where such reproduction or rendition occurs."

- 29 STA't. $48 \mathrm{r}$.

7 The present British Copyright Act is similar to our Act of 1897 in that it does not contain the "for profit" requirement. In a recent review of the British law, the Copyright Committee of the British Board of Trade, in a report presented to Parliament in October, 1952, found (RePoRT, par. I78): "In the first place we have had to consider whether the right of public performance in respect of copyright material in the ordinary sense, i.e., the rights protected under Section $I$ of the Copyright Act, is justified. We have come to the conclusion that it is. Plays and musical works are written to be performed, and dramatists and composers are entitled under all known canons to derive their incomes from the power to control performance. The fact that these works have been written is a pre-requisite to their attracting other rights. We make recommendations elsewhere to meet cases where these rights are used, or alleged to be used, in a monopolistic manner: otherwise we recommend no alteration in the law in this respect." 
Commercial establishments which had been accustomed to using music without paying for it strenuously opposed the attempt on the part of composers and authors to secure payment for public performances of their works.

The individual copyright owners were financially unable to check on each of the establishments at which musical compositions were performed. Even if they had been able to do so, individual licenses would have little value because commercial users needed ready access to practically all copyrighted music demanded by the public. In order to administer this right of public performance for profit, Victor Herbert and eight other outstanding composers and publishers organized in $\mathrm{r}_{91} 4$ the American Society of Composers, Authors and Publishers. ${ }^{8}$

The early efforts of the Society to protect its members were resisted by restaurants, cabarets, and hotels which took the position that there was no public performance of copyrighted music for profit at these establishments because no specific charge was made for admission to the premises where the performances occurred. This position was firmly rejected by the United States Supreme Court in Herbert $v$. Shanley Co., where Mr. Justice Holmes, speaking for a unanimous court, said: ${ }^{0}$

If music did not pay it would be given up. If it pays it pays out of the public's pocket. Whether it pays or not the purpose of employing it is profit and that is enough.

Subsequent to the Shanley decision, the courts decided that radio broadcasts of copyrighted musical compositions, ${ }^{10}$ reproductions of radio broadcasts by loudspeakers installed in hotel lobbies, ${ }^{11}$ and performances in motion picture theatres ${ }^{12}$ and dance halls, ${ }^{13}$ all came within the meaning of Section $\mathrm{I}(\mathrm{e})$ of the Copyright Act. The development of new means of reaching a mass audience through radio, television, and recordings has altered the primary market for musical compositions from printed copies to public performances of these works. Radio and television have made enormous demands for ever-new material. As a result of the constant repetition of a hit song in broadcasting and juke boxes, songs which would have remained popular for long periods in the days before the advent of radio and television now reach their peak and disappear within a matter of weeks. The top professional writers often have long periods of sterile composition between hits. Yet a current hit frequently yields the composer less than $\$ 1500$ in sheet music royalties.

\footnotetext{
${ }^{8}$ For a more complete discussion of the subject, see Finkelstein, Public Performance Rights in Music and Performing Right Societies, in 7 Copyright Problems Analyzed 69-85 (1952).

242 U. S. 59r, 595 (19I7).

${ }^{10}$ M. Witmark \& Sons v. L. Bamberger \& Co., 291 Fed. 776 (D. N. J. 1923); Jerome H. Remick \& Co. v. American Automobile Accessories Co., 5 F.2d $4 \mathrm{II}$ (6th Cir. 1925); Associated Music Publishers v. Debs Memorial Radio Fund, I4I F.2d 852 (2d Cir. 1944) (broadcast on sustaining program of station owned by non-profit corporation).

${ }^{11}$ Buck v. Jewell-LaSalle Realty Co., 283 U. S. I9I (193I); see also Society of European Stage Authors and Composers v. New York Hotel Statler Co., 19 F. Supp. I (S. D. N. Y. r937) (receiving sets installed in hotel bedrooms).

${ }_{12}$ M. Witmark \& Sons v. Pastime Amusement Co., 298 Fed. 470 (E. D. S. Car. 1924), aff'd, 2 F.2d I020 (4th Cir. 1924).

${ }^{13}$ Dreamland Ballroom v. Shapiro, Bernstein \& Co., 36 F.2d 354 (7th Cir. I929).
} 
Before the days of radio, the average hit song sold upwards of $1,000,000$ copies. ${ }^{14}$ Today many hit songs sell less than 50,000. Thus performances have of necessity become the composer's mainstay, and his primary source of income.

\section{Music As an Advertising Medium}

The new electronic inventions have greatly affected the economic lives of those who write and publish music. They have brought together the arts and sciences in a manner undreamed of little more than a quarter century ago.

Music has in fact become one of the most important ingredients in the modern industrial scheme. It is true that not so long ago, as time is reckoned, the Minnesingers wandered from place to place singing for whatever their local patrons would contribute. The wandering minstrels were not wealthy in worldly goods; they were accustomed to an attire of "shreds and patches," to borrow the words of W.S. Gilbert. They were even outlawed under laws lumping together "bards, vagabonds, and beggars."15 But today's minstrels are part of the warp and woof of our society. Their comings and goings are noted on the society pages of the daily papers; indeed, entire magazines are devoted to their doings. Their commercial importance may be appraised by a single example-the fact that the National Broadcasting Company, a subsidiary of the Radio Corporation of America, considers it good business to place the present-day minstrel, Milton Berle, under a long-term contract for a guaranteed payment of approximately $\$ x, 500,000 .^{16}$

Why do these minstrels earn so much today-and how has it happened that they have won such a place in the sun? Obviously because they are successful in doing what every other successful businessman is doing-selling automobiles, cigarettes, soap, spirits, steel, utilities, washing machines, and so forth. Do not think for a moment that because these minstrels provide fun for you, they are working merely for the fun of it. Entertainment today is big business and it attracts big men-men and women who judge success by the same values as those who make use of their services. 'Tobacco companies spend millions of dollars on entertainment annually-not as an end in itself, but as a means of attracting an audience for the sales talk, or as we now say in radio and television, for the "commercial."17 Without the siren appeal of music, the "commercial" would fall on deaf ears. As a leading columnist recently writing on "Big Steel and Show Biz" observed, industry is yielding to the slogan: "There's no business like show business."18

\footnotetext{
${ }^{14}$ See Henderson, The Law of Copyright Especially Musical, First Copyright Law Symposium I62 (I939).

${ }^{15}$ Scotch edict of Aug. 23, x609, quoted in William Keddie (ED.), Cyclopedia of Literary and Scientific ANEcDote ig (1859).

${ }^{10}$ The Billboard, Jan. I0, I95I, p. I, and Mar. 3I, I95I, p. 2. An advertiser wishing to engage the Berle program for a single hourly broadcast must pay NBC $\$ 70,000$ for talent plus the usual time charges. General Motors sponsors this program for approximately 35 weeks per year at a cost of almost $\$ 2,500,000$ for talent alone. Sponsor Magazine, Nov. 1953, p. 45. The time charge for a single broadcast on the full NBC network would be approximately $\$ 70,000$.

${ }^{27}$ Tobacco companies spent $\$ 38,600,000$ for radio and television in $x 95 x$; and $\$ 44,400,000$ in 1952 . Telecasting Yearbook io (I953); Brondcasting Yearbook 12 (1953).

${ }^{18} \mathrm{H}$. I. Phillips, in N. Y. World Telegram, Nov. 4, 1953.
} 
So far we have considered only the performer and his employers-the broadcaster and the advertiser. The world recognizes now that if you want to hear a tune you' must pay the piper. But what about the men and women who pen the piper's tunes? Where would the cigarette manufacturers and broadcasters be without them? Would the casualty lists among newspapers in recent years have been as high if music were eliminated from radio and television? The inescapable fact is that all these media compete for the advertiser's dollar, and the advertisements are placed in whatever medium attracts the greatest audience (called "circulation" in the terminology of periodicals) at the lowest price per reader, listener or viewer. Television is such an effective medium that advertisers pay as high as \$1095 for a 20-second announcement delivered over a single New York station. ${ }^{10}$ A wit recently observed that it costs over $\$ 50$ to sneeze on television.

\section{E. The Growth of the Broadcasting Industry}

Radio and television combined grossed approximately $\$ 800,000,000$ in $1952 . .^{20}$ It is estimated that the figure for 1953 will be $\$ 915,000,000{ }^{21}$

The growth of broadcasting in the post-war period may be illustrated by the following tables:

\begin{tabular}{|c|c|c|c|c|}
\hline \multirow[b]{2}{*}{ 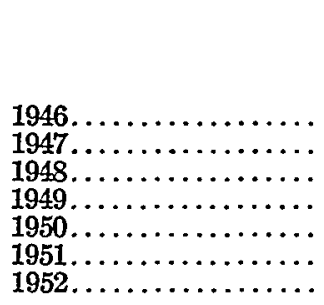 } & \multicolumn{3}{|c|}{ Number of Licensed Stattons ${ }^{22}$} & \multirow[b]{2}{*}{$\begin{array}{l}\text { Total } \\
1,015 \\
1,352 \\
1,842 \\
2,353 \\
2,658 \\
2,863 \\
3,011\end{array}$} \\
\hline & $\begin{array}{r}A M \\
961 \\
1,298 \\
1,693 \\
1,963 \\
2,118 \\
2,248 \\
2,333\end{array}$ & $\begin{array}{r}F M \\
48 \\
48 \\
142 \\
377 \\
493 \\
534 \\
582\end{array}$ & $\begin{array}{l}T V \\
6 \\
6 \\
7 \\
13 \\
47 \\
81 \\
96\end{array}$ & \\
\hline \multicolumn{5}{|c|}{ INCOME OF BROADCASTING INDUSTRY ${ }^{23}$} \\
\hline 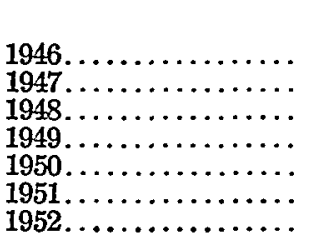 & $\begin{array}{r}A M \text { and } F M \\
\$ 322,600,000 \\
363,700,000 \\
408,700,000 \\
416,600,000 \\
445,900,000 \\
450,400,000 \\
473,100,000\end{array}$ & & & $\begin{array}{r}\text { Tolal } \\
\$ 322,600,000 \\
363,700,000 \\
417,900,000 \\
450,900,000 \\
551,800,000 \\
686,100,000 \\
797,300,000\end{array}$ \\
\hline
\end{tabular}

The growth of television has been striking indeed. Between 1949 and $x 952$ its annual receipts from advertisers increased almost ten-fold-from $\$ 34,300,000$ to $\$ 324,200,000$. The $27,463,000$ television sets now in use ${ }^{24}$ cost the public over two billion dollars-to use a conservative estimate of only $\$ 75$ per set.

\footnotetext{
${ }^{10}$ Variety, Nov. 25, 1953, p. 28, pointing out that the rates for Station WNBT had been increased five times since Nov. x, 1950; Variety, Sept. 16, 1953, p. 21, announcing a rate of \$ro75 per 20-second announcement for Station WCBS-TV, quotes CBS as stating that "time that was considered valueless less than six years ago, today sells for $\$ 53.75$ per second." The WNBT rate is slightly higher.

${ }^{20}$ FCC Pub. Notice 89912, Apr. 30, 1953.

21 Billboard, Dec. 5, 1953, pp. 1, 3 .

${ }^{22}$ ETGHTEENTH FCC ANN. REP. I2I (1953).

${ }^{23}$ Compiled from FCC Annual Reports (1947-r952), FCC Pub. Notice 89912, Apr. 30, 1953, and FCC Pub. Notice 93525, July 3r, 1953.

24 Broadcasting-Telecasting, Nov. $x 6$, I953, p. 122 .
} 
F. Composer's Share of Payments by Advertisers to Broadcasters

Since music is the backbone of the billion dollar broadcasting industry, it is appropriate that we examine what part of its income goes to those who write and publish the nation's music.

The payments by broadcasters for the use of music-the most valuable ingredient of their entertainment package-cannot be considered in a vacuum. They must be considered in relation to other payments involved in getting the advertising message across to the public.

The following chart which appeared in a recent issue of the leading broadcasting journal graphically shows this relationship $:^{25}$

\section{EXPENDItURes for Radio and TV Programs}

I952

S $797,300,000$

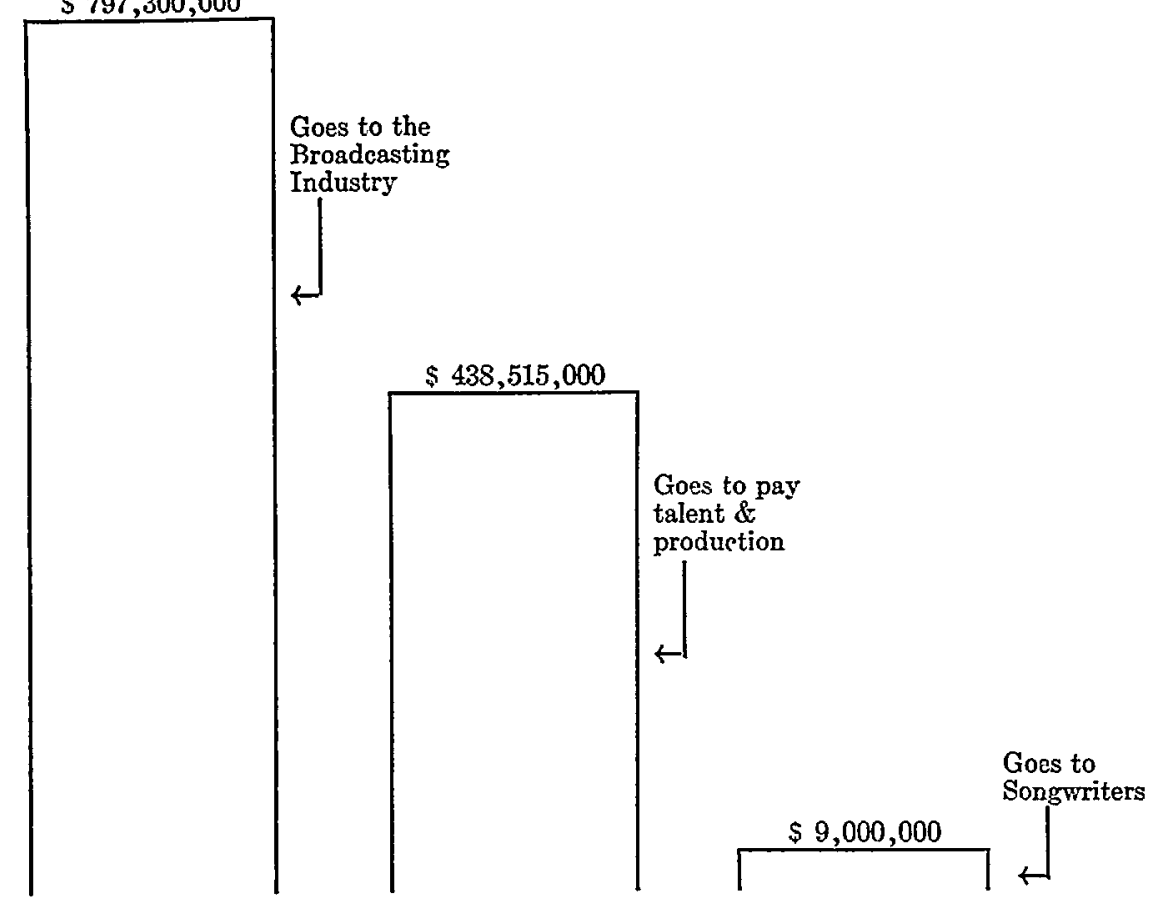

From the foregoing it appears that only two cents of each dollar spent by advertisers to deliver their messages on radio and television goes to the writers and publishers of music. ${ }^{26}$

${ }^{25} I d$. at 38 , referring to plaintiff's exhibit in an action brought by certain songwriters charging antitrust law violations. Arthur Schwartz v. Broadcast Music, Inc.

${ }^{30}$ The sums paid to ASCAP are divided equally between writers and publishers, after the payment of operating expenses which amount to less than 20 per cent of the ASCAP income. A large part of the sums paid by broadcasters to their own licensing organization, Broadcast Music, Inc. (BMI) is spent in providing special services for broadcasters. According to the I953 annual report of BMI, 43.9 per cent of its income was ear-marked for expenses. 


\section{Regulation of Performing Right Societies}

The two large organizations licensing performing rights today are regulated by consent decrees. ${ }^{27}$.

In I94I, as a result of a dispute between the broadcasting industry and the writers and publishers constituting the American Society of Composers, Authors and Publishers (ASCAP), both ASCAP and a licensing organization created by the broadcasters (Broadcast Music, Inc. [BMI]) submitted to regulation by consent decree. ${ }^{28}$

We shall limit our discussion largely to statutory regulation. In as much as statutory regulation of performing right societies can be justified only in the public interest, it will be necessary to consider that interest

(I) as applied to government regulation generally;

(2) as a means of carrying out the copyright provision of the Constitution which is designed to encourage authors to create new music for the public enjoyment;

(3) so as to avoid interruption, as far as possible, of the public's enjoyment of the best available music;

(4) so as to safeguard the industries which depend upon music against arbitrary demands by performing right societies; and

(5) so as to safeguard writers and publishers of music (members of performing right societies) against boycotts by collective groups of commercial users.

There have been efforts at statutory regulation in the several states of the United States as well as in foreign countries. ${ }^{29}$ In some countries such as Italy, Switzerland, Holland, the Scandinavian countries, and Mexico, performing right societies are given statutory monopolies with concomitant governmental right of supervision. We shall not consider those statutes here. Regulation of a different sort prevails in Canada, where a Copyright Appeal Board annually passes upon the reasonableness of rate schedules of Canadian performing right organizations. ${ }^{30}$ This statute and its operation will be considered in some detail.

In order to evaluate the public interest in relation to performing right societies, we must trace their development, their scope, and the self-imposed limitations on their activities.

\section{A. Development of Performing Right Societies}

It is natural that we should find France to be a champion of its writers. France

${ }^{27}$ Regulation by consent decree is discussed in this symposium by Sigmund Timberg, former chicf of the Judgment Section of the Antitrust Division of the Department of Justice.

${ }^{28}$ United States v. Broadcast Music, Inc., decree entered May I4, I94I, Eastern District, Wisconsin; United States v. ASCAP, decree entered Mar. 4, x94I, Southern District, New York.

${ }^{29}$ See statutes referred to in note 43 , infra. In addition, statutes were passed and later repealed in Kansas, Laws of I939, c. 306; repealed, Laws of I943, c. 212, \$3; Montana, Laws of I939, c. 123, repealed, Laws of $194 \mathrm{I}$, c. 40; Nebraska, Laws of 1937, c. 138; repealed, Laws of 1945, c. 139, 59; Tennessee, Public Acts of 1937 , c. 212; repealed, Public Acts of 1943, c. 12; and Wisconsin, Wis. Sturs. 1945, c. 177, repealed, Laws of I951, c. 572.

${ }^{30}$ Copyright Amendment Act of 1931, c. 8; amended Copyright Act of 1935, c. 18; and Copyright Act of 1938 , c. 27. 
has been conscious of the important role played by its authors and intellectual leaders in world affairs. The use of French as the language of diplomacy has been a great factor in building up world friendship, just as our contribution of dollars under the Marshall Plan is likely to win friends for us among nations of the world. Beaumarchais, who figured prominently in both the American and French revolutions, and is noted as the writer of Figaro, was the founder of the first society of dramatic authors on July $3,{ }^{1} 777^{31}$

As French music grew in importance, it became necessary for composers and authors to follow the Beaumarchais example. They formed the French Performing Right Society (Societe des Auteurs, Compositeurs et Editeurs de Musique) in I857. The British Society (Performing Right Society, Limited) and the American Society (ASCAP) were formed in IgI4.

Brietly, a performing right society has the following attributes:

(I) It licenses music in bulk. A performing right society, in its true sense, is an association of composers, authors, and publishers of musical works banded together for the purpose of licensing the public performance of their works on a bulk basis in situations where it would not be feasible to license the works individually or to detect and secure redress for unauthorized performances.

(2) It acts as a clearing house for music. As stated above, performing right societies issue licenses on a bulk basis. The royalties received from such licenses are distributed among the members of the societies on a basis which takes into consideration primarily the performances of the members' works. Other factors in evaluating the nature, character, prestige, and general standing of the members' works are also considered. Not all uses are reported. Radio and television performances serve as a primary factor in determining the apportionment of royalties from all fields.

(3) It is self-regulatory by imposing certain limitations upon its own activities. These include:

(a) It deals only in non-dramatic performance rights. Performing right societies are not concerned with licensing dramatic works as such, whether they be dramatic plays, musical comedies or operas. ${ }^{32}$ If the performance given is of a dramatic nature, it requires substantial preparation in advance and there is sufficient opportunity to negotiate for a license with the owner of the dramatic rights.

(b) It issues its collective license only in those cases where the amount involved for each use is so small and the use of such an ephemeral nature as to require bulk licensing in advance of the performance and the elimination of individual applications for permission to perform specific works.

(c) Its license is available to all users engaged in giving non-dramatic public performances for profit.

${ }^{31}$ Georges E. Lemaitre, Beaumarchais 257 (I949).

32 The individual songs as well as the instrumental scores of dramatico-musical works are included in the Society's repertory to the extent that non-dramatic performances of such works may be given, e.g., renditions of a song from a musical comedy without dialogue, scenery or costumes. 
(d) It is not concerned with the publication of its members' works. That is arranged between the writer and the publisher.

(e) It has no part in arrangements concerning the recording of a member's works. That is usually arranged by the individual publisher pursuant to his agreement with individual writers.

(f) It must not attempt to promote the popularity of the individual works in its repertory. That is the responsibility of each of the members acting individually.

The self-regulation of performing right societies to a very large extent limits the sphere of their activities and stimulates competition between the respective members because a member's share in the distribution of royalties depends primarily on the users' performances of each member's works.

\section{B. Performing Rights Must Be Licensed Collectively}

Whenever the subject of licensing performing rights has been examined by governmental agencies, they have concluded that performing right societies are a necessary part of our economic structure. The Copyright Committee of the British Board of Trade, after an exhaustive study, made the following report to Parliament in October, $1952::^{33}$

It must be obvious that an individual composer, whose work is played in numerous halls throughout the country on various occasions and by many performers would have no expectation whatever of collecting royalties to which he is justly entitled if he was his own collector. It is only in association with others and through an organisation which can authorise performances, attend to the business of collecting dues, and bring infringers to book, that there could be any prospect of an individual composer securing an income from the public performances of his music. It was because of these considerations that the Performing Right Society was formed to protect the performing rights of composers, lyric writers and publishers who vest their performing rights in the Society. This method, too, is not without its advantages to promoters of public entertainment. They are covered by one licence which protects them against actions for infringement instead of having to obtain licences from innumerable copyright owners.

Our own Department of Justice has summarized the situation as follows: ${ }^{84}$

Prior to $19 \mathrm{r}_{4}$, individual authors, composers and publishers realized little in the way of royalties for the public performance of their compositions. It was impossible for individuals to maintain constant surveillance throughout the forty-eight states and to collect royalties for each performance of their musical compositions. It was also difficult for them to prosecute each establishment which performed their music without the payment of royalties. The problem of collecting royalties and protecting copyrights was met by joint action of the authors, composers and publishers. Where individual action could be sporadic and ineffectual, combined resources and vigilance and concerted threats of prosecution for copyright infringement enabled the copyright owners to force the many users to pay for the public performance privilege.

${ }^{33}$ Repont of the Copyright Committee, CMd. No. 8662, at 45 (No. 127).

34 Complaint in United States v. ASCAP, filed June 23, 1947, Southern District New York, Civil Action 42-245, Par. 9 . 
C. Regulation and the Public Interest

(I) If owners of property rights are to be regulated, there should be a genuine need for this in the public interest. All regulation involves the surrender of certain liberties. Mr. Justice Holmes reminded us: "To know what you want and why you think that such a measure will help it is the first but by no means the last step towards intelligent legal reform. The other and more difficult one is to realize what you must give up to get it, and to consider whether you are ready to pay the price."35

One of England's great jurists pointed out that because an author is deprived of all right to control his work after a limited period of time, "the law of copyright has a communistic character."36 He warned: ${ }^{37}$

Limit in the interests of the State the duration of property in books, if you like, but recognize that the same arguments may be used to limit the duration of property in land, the power of bequest at death, and the devolution of the property of an intestate. And above all, a caution which is most necessary in arguing the matter, and dealing with questions of so-called "justice," "right," and "utility," let us be careful that we understand what we mean by these terms, for though such an investigation may be tedious to our lofty intellects, perhaps even fatal to our pet arguments, it will certainly result in greater clearness and brevity, and less idle declamation.

The Constitution of the United States prescribes two requirements to safeguard the public interest in works of authors, namely, that the rights granted to authors must be (a) limited in time, and (b) exclusive.

(2) There is a public interest in carrying out the spirit of the constitutional provision concerning copyright laws. In as much as performing right societies deal exclusively with copyrighted musical works, our examination will require a study of the public interest in copyrights generally and in music in particular. Most of the world's music is in the public domain-that is, it may be used for any purpose without anyone's consent, and without payment of royalties-at least, in the United States. $^{38}$ This applies to the great operas of Bizet, Gounod, Mozart, Rossini, Verdi, Wagner, Weber-to name but a few-the symphonies of Beethoven, Berlioz, Brahms, Schubert, Schumann-in fact, the vast bulk of the standard repertoire of symphony orchestras-the gems from Gilbert and Sullivan, and the great folk songs including those of Stephen Foster and of many composers who are remembered only by their works. We are dealing only with works created or published during the past fiftysix years-the maximum term of copyright in the United States.

Everyone will agree that a nation without music would be a dreary place indeed. Napoleon, in fathering the copyright law of a nation that has always been a leader in music and literature, said, "Music, of all the liberal arts, has the greatest in-

38 Collected Legal. Papers 307 (1920).

${ }^{30}$ J. E. Scrutton, The Laws of Copyright 290-29I (I883).

st Id. at $29 \mathrm{I}-292$.

${ }^{38}$ In some countries the principle of domain publique payant is applied, that is, payment must be made for the commercial use of even public domain music. The royalties so obtained are used to subsidize opera houses, etc. 
fluence over the passions and is that to which the legislator ought to give the greatest encouragement."39

The founding fathers of America were also aware of the importance of encouraging the creation of new works by appropriate federal legislation. The Congress was therefore empowered "to promote the Progress of Science and useful Arts, by securing for limited Times to Authors and Inventors the exclusive Right to their respective Writings and Discoveries." 40

This provision was intended to make the subject of copyright a matter of national concern to the same extent as the other subjects expressly entrusted to Congress, namely, financing of the government, regulation of commerce, coinage, post offices, piracy on the high seas, the maintenance of the army and navy, and the declaration of war.

Thus one aspect of the public interest is that encouragement must be given to the creation of new music by safeguarding the rights of authors through giving them certain exclusive rights in their works for limited periods of time.

As we have pointed out, performing right societies deal with only one right embraced in a copyright-namely, the right of public performance for profit.

In summarizing the necessity for performing right societies, Atkin, L. J., said: ${ }^{41}$

It was found that it was difficult for authors to recover the proper remuneration for their performing rights in respect of infringements that might take place all over the country; each author would have to first of all ascertain whether his work was performed or not, and then would have to enter into the necessary correspondence with regard to it and if the correspondence was insufficient to protect him, to undertake the necessary litigation and, on the other hand, if persons desired to be honest and pay for the property that they were using, it was not very easy for them to ascertain in all cases where the copyright was or whom they had to ask for permission to perform.

(3) There is a public interest in a free flow of music. Before the days of simultaneous mass communication, there was no problem of collective interference with the free flow of music. Most musical entertainment occurred at home around the piano. Pianos or organs were almost as much a part of the family scene as radio and television sets today. The young folks gathered around a piano on Saturday evenings and entertained themselves and each other. Sheet music was as indispensable to the enjoyment of a piano as the piano roll was for the automatic piano of a later day. The player piano and the phonograph did not interefere with the individual selection of musical fare. They merely substituted a record or music roll in place of sheet music, and provided a mechanical means of reproduction in place of the individual performer. It remained for radio, and then television, to provide a means of mass communication that left very little for individual choice. A listener or viewer can turn the knob from one station to another; but for the most part the fare is apt to be substantially the same, except for a few educational and

${ }^{30}$ Quoted in C. F. James, THe Story of Performing Right Society 133 (I951).

${ }^{10}$ U. S. Const. Art. I, $\$ 8$.

${ }^{4}$ Performing Right Society v. Thompson (I9r8), quoted in C. F. JAMEs, The Storr of Perforsino RIGHT Societr 27 (195r), opinion digested in 34 T.L.R. 35 I (I9r8). 
so-called "good music" stations like WQXR in New York City. In large cities there are also foreign language stations; and some stations devote more time to sports events than do others.

If a substantial number of radio or television stations should combine to boycott certain music, or if a substantial number of composers were to boycott the stations, the public would suffer greatly. The American public has been induced to buy well over 100,000,000 radio and television receiving sets ${ }^{42}$ with the expectation of almost unlimited access to the best entertainment available. If these sets had averaged only \$10 each, they would represent an investment of $\$ 10,000,000,000$ - apart from the cost of servicing and electricity. When in I94I these buyers of sets were deprived of all opportunity of hearing the songs of Cole Porter, Irving Berlin, Jerome Kern, Victor Herbert, Vincent Youmans, George Gershwin, Rudolf Friml, Richard Rodgers, Oscar Hammerstein II, and other great American composers, the value of radio sets was substantially lessened for those who enjoyed the best in popular music. "Pal Joey," by Richard Rodgers and Larry Hart, was then playing on Broadway, but the songs from the show were not heard on the air. When the show was revived in January 1952, the songs such as "Bewitched, Bothered and Bewildered" and "I Could Write A Book" had their first widespread public airing. It is unimportant for our purposes to determine whether the impasse between ASCAP and the broadcasting industry in 1940-4I was the fault of the creators of music or the owners of broadcasting networks and stations. The fact is that the public did not hear the music to which it had been accustomed, but rather was fed such public domain works as Stephen Foster's "Jeannie With the Light Brown Hair" ad nauseam, solely because they were in the public domain, and not because of genuine popular demand. If the public has a right to be protected against the results of such an impasse, regulation of performing right societies may be an appropriate remedy.

To understand our problem better, it would be well to analyze the make-up of a performing right society, and its dealings with collective groups of users.

The American Society of Composers, Authors and Publishers (ASCAP) was organized in 1914 under the leadership of Victor Herbert and his attorney, Nathan Burkan. At the end of the first year of its existence, it had I70 writer members and 22 publisher members. The writer members were divided into two classes-composers and authors. The original articles of association provided that royalties were to be distributed on the basis of one-third to composers, one-third to authors, and one-third to publishers. Early in its history, the Society discovered two serious defects in its structure: (I) The apportionment of only one-third of the royalties to publishers made it impossible to attract the so-called standard publishers, that is, those who published works of a more serious nature. This group of non-members included such well-known houses as G. Schirmer, Inc., Carl Fischer, Inc., Oliver Ditson, Theodore Presser, etc. (2) The members made only a non-exclusive grant to the Society, with the result that when the Society prosecuted infringers, the latter

\footnotetext{
42 In 195 I the United States had five-eighths of all receiving sets reported by the United Nations for 128 countries. SEVENTEENTH FCC ANN. REP. I29 (1952).
} 
often claimed that they had secured a license, usually oral, from the member. Both these problems were met in rg2I by the following changes in the Society's Articles of Association:

(I) The writers collectively (composers and authors) agreed to a 50-50 distribution as between them and their publishers.

(2) The Board of Directors was to be composed of twelve writers and twelve publishers.

(3) In order to give the standard writers and publishers a further incentive, it was agreed that thereafter there should be at all times at least three standard writers and three standard publishers on the Board.

(4) The members agreed to make an exclusive grant of performing rights to the Society.

In I94I, a consent decree enjoined the Society from accepting a grant of exclusive rights from its members. However, the Society was permitted to attach certain conditions as a limitation on individual licensing by its members. These restrictions (so far as they related to direct dealings between members and users) were removed in the amendment of this decree in 1950 . Members may now license users without restriction, but they may not delegate their licensing authority to another licensing organization.

(4) What safeguards are necessary to protect the public interest involved bettveen commercial users of music and performing right societies? A user of music such as a dance hall, night club, or radio or television station, must be able to perform all of the compositions currently in demand by the public. In order to do this feasibly, it must arrange for bulk licenses in advance from any organization that controls a substantial number of currently popular works. If any composition should be performed without such a license, infringement of copyright results with the consequent liability for damages, costs, and counsel fees under the copyright law.

Most users are organized into associations and deal collectively with organizations controlling performing rights. For the most part, there is substantial equality of bargaining power and agreements are worked out which represent compromises on both sides. If a stalemate arises, however, the music of the particular organization is not resorted to by the users and the public is denied an opportunity to hear and enjoy compositions which have been written, published, and copyrighted pursuant to an avowed national policy to encourage the creation of such national works. Such a result is injurious to the public and should be avoided if possible. If performing right societies are to be regulated, it must be for the purpose of securing for the public access to copyrighted works on a reasonable basis. Neither the associations of copyright owners nor those of impresarios (owners of dance halls, hotels, or broadcasting stations) should be in a position to deprive the public of access to these works by performances in the respective fields.

In the light of this background, we may examine some past and present statutory regulation both in the United States and elsewhere. 
D. Regulatory Statutes

I. The United States. Regulation of performing right societies in the United States takes two forms. One type of statute requires the filing of all contracts entered into between a society and the users in the state, within a given period of time after the contract is executed. ${ }^{43}$ Another type of statute requires the filing of a list of copyrights claimed by the society together with a schedule of charges for the use of the compositions in the catalogue.

The object of such a statute is to enable each user of copyrighted music to find out what other users are paying so that he may be assured of non-discriminatory treatment in dealing with performing right societies.

Another type of statute proscribes price fixing by combinations of composers, authors or publishers; permits broadcasters in the state to pick up and rebroadcast performances of such combinations if the initial performances are authorized and emanate from points outside the state; and then proceeds to enact measures which would prevent even an individual author from licensing performing rights independently of the sale of copies of the work. ${ }^{44}$ To the extent that price-fixing combinations were declared illegal, the United States Supreme Court held that this statute did not violate the federal constitution, but the Court refused to pass upon the remaining portions of the statute. ${ }^{45}$ When the statute was subsequently tested in the Florida state courts, it was held, in Palm Tavern $v . A S C A P, 46$ that ASCAP was not a price fixing combination condemned by the statute because of the following limitations imposed upon it by a consent decree entered in a federal court in I94I:

(a) The Society obtained only non-exclusive rights from its members;

(b) the Society is barred from discriminating between licensees similarly situated;

(c) the Society is required to issue licenses on a per composition basis;

(d) the members of the Society's Board of Directors are elected directly by the membership;

(e) the previous requirement that an applicant for writer membership have had five published compositions has been changed so that a writer of a single regularly published composition is eligible if he actually practices the profession of writing music, or the text or lyrics of musical works.

The provisions of the federal consent decree relied on by the Florida court were supplemented in an amended federal decree entered in I950 which assures to the members the control of licensing their works on an individual basis whenever a user wishes to deal on a basis of obtaining a license for individual works rather

${ }^{43}$ Such statutes have been enacted in Vermont (Versront Rev. Stat. c. 54, \$II75 (I947)); Nebraska (Neb. Rev. Stat. \$59-I402 (I943)); North Dakota (N. D. Rev. CoDE, \$47-2105 (I943)); Kansas (Gen. Stat. Kan. $\$ 57-205$ (1949)); Florida (2 FlA. Stat. $\$ 543.23$ (195I)).

"Laws of Fla., 1937, Ch. I7807; the provision requiring a license of performing rights upon the sale of copies of the work was repealed by a 1939 statute which barred the issuance of blanket licenses unless an optional plan of payment on a per performance basis was made available. Laws of Fla., 1939, Ch. 19653 .

'W Watson v. Buck, 313 U. S. 387 (1941).

${ }^{10}{ }_{153}$ Fla. 544, I5 So.2d 19I (1943). This decision was followed in Watson v. ASCAP and BMI. 
than for the repertory of the Society in bulk. In such cases the Society is barred from issuing a license unless requested to do so by both the user and the member. Other provisions insuring a democratic administration of the affairs of ASCAP are detailed in Mr. Timberg's article which appears in this symposium.

The provisions of a Nebraska statute were so onerous that the Society felt that it could not represent its members in the state of Nebraska and returned the rights to them for that state. Thereupon individual members, having discovered that their works were being infringed in Nebraska, brought infringement suits. Failure of the members to comply with the statute was held not to be a defense. ${ }^{47}$ The Nebraska statute then was repealed at the request of the users. Similar statutes have also been repealed in Montana, Tennessee, and Kansas.

A third type of statute would merely impose a confiscatory tax and thus discourage the licensing of performing rights. Such a statute imposing a 25 per cent tax was enacted in Wisconsin but was never enforced. It was finally repealed. ${ }^{48}$

2. Canada. Canada enacted a regulatory statute in 193r. ${ }^{49}$ The Act relates to organizations which acquire copyrights of either dramatico-musical or musical works and which grant licenses for the performances of such works in Canada. Such organizations must file lists of works in current use licensed by the Society. The licensing organization must file a schedule of rates with the Minister at the Copyright Office each year before November $x$.

Any organization failing to file such a list is barred from bringing an infringement suit unless the consent of the Minister is given in writing.

The schedule of rates filed by the organization must be published by the Minister in the Canada Gazette as soon as practicable. Anyone objecting to these rates has 2I days to file his objections.

The hearing on such objections is then held before the Copyright Appeal Board consisting of three members appointed by the Governor in Council. The Chairman of the Board must be a person who holds or has held judicial office. Traditionally he has been the President of the Exchequer Court. The two other members must be selected from officers of the public service of Canada. At the present time the three members are Mr. Justice Thorson of the Exchequer Court, Charles Stein, Under-Secretary of State, and Paul Fontaine, Assistant Deputy Minister of Justice.

No fees or emoluments of any kind other than traveling expenses are paid to members of the Board. The Board may call to its aid in an advisory capacity the services of any person having technical or special knowledge of the subject matter and may pay such persons such fees and traveling and living expenses as may be approved by the Minister.

\footnotetext{
${ }^{47}$ Interstate Hotel Co. of Nebraska v. Remick Music Corp., I57 F.2d 744 (8th Cir. 1946); Feist v. Young, I38 F.2d 972 (7th Cir. 1943). See also Woodmen of the World Life Assurance Society v. ASCAP, 66 U.S:P.Q. 193 (Neb. Sup. Ct, I945).

${ }^{48}$ Wis. Stat. c. I77 (1945), repealed Laws of I951, c. 572.

'D Copyright Amendment Act of 1931, c. 8; amended Copyright Act of 1935, c. 18; and Copyright Act of 1938 , c. 27 .
} 
The Copyright Appeal Board may refuse the rates even though no objections thereto have been filed.

The rates fixed are effective for a one-year period. If a user has tendered or paid the fees approved by the Copyright Appeal Board, he is not subject to an infringement suit even though no license has actually been issued. This provision seems reasonable with one limitation. There should be an express provision that such royalties must be tendered before suit is brought. It would be unfair for a defendant to refuse to pay license fees on demand and then to defeat a lawsuit by tendering payment after a suit is filed.

\section{E. Scope and Objectives of Regulation by Statute}

Any statutory regulation, therefore, should accomplish the following:

(I) It should be national (rather than statewide) in scope; otherwise, there would be no assurance of uniformity in rates;

(2) it should apply only to organizations engaged in bulk licensing;

(3) it should impose a system of compulsory licensing;

(4) the Society should be required to file a schedule of rates annually;

(5) objections should be heard whether raised by individual users or groups of users;

(6) the rates should be determined by a permanent agency to avoid inconsistent determinations and expensive hearings;

(7) the tender of license fees so determined should be a defense to an action for infringement if the tender is made before bringing suit;

(8) users who act collectively should be barred from boycotting the music of societies complying with the foregoing provisions;

(9) consideration should be given to whether such societies should be regulated internally concerning

(a) rules determining eligibility to membership;

(b) the composition of the Board of Directors; and

(c) the distribution of royalties;

(Io) a society complying with all of the foregoing requirements should be exempt from application of the antitrust laws if it refrains from

(a) acquiring any rights in musical works other than the right of nondramatic public performance of such works;

(b) publishing musical works;

(c) recording such works; or

(d) exploiting or promoting the individual works of members.

If the Society is required to admit to membership all applicants who comply with certain standards, it is entirely possible that virtually all the writers and publishers of music in America may become members. If that should happen, the Society should not be charged with becoming an illegal monopoly as a result of compliance with the admission policy laid down by the regulations. 
Conclusion

In the licensing of performance rights, writers and publishers of music are confronted by a dilemma: the rights are worthless to their creators and to commercial users when licensed singly; yet the moment they are combined to become a marketable package, they are subject to attacks charging that such a combination is illegal. When our antitrust laws were written in 1890 and I9I4, there was no market for these rights in the United States. Likewise when performing rights were first recognized in the 1897 Copyright Act, and again in the rgog revision, there had not yet arisen any traffic in these rights. Commercial radio, television, and juke boxes are all a product of the inventive genius of the period following the first World War.

Music has taken on a new value because of scientific developments of inventive genius; in turn, the composer furnishes the entertainment material which provides a market for the new devices in the field of mass communication.

There would be few sales of radio and television receiving sets, and few industries would use broadcasting as an advertising medium, if there were not a constant stream of entertainment to sweeten the advertising message. Even in countries where broadcasting is a government monopoly, and a tax is collected from each owner of a receiving set, a portion of that tax is paid by the government to the domestic performing right society. That society accounts to societies in foreign countries for the domestic use of foreign music. In turn, these payments are allocated to the respective writers and copyright owners. These arrangements would be impossible if there were no performing right societies.

Any legislation, whether state or national, which interferes with the clearing house functions of performing right societies would be dangerous and destructive. Yet whenever combination becomes necessary, as in the case of the marketing of performing rights, it is appropriate to examine on a national basis the proper sphere of such combined activities. At the same time, it must be recognized that users have always dealt collectively in negotiating uniform rate schedules with such societies. Any regulation of performing right societies, therefore, which fixes rates for the commercial use of their music should also be binding upon large-scale users. In any legislation that may be considered, the public interest should always be paramount. That interest is protected if (a) the creation of new works is adequately encouraged by making the monetary rewards attractive; (b) the works are made available to users, when licensed collectively, on a reasonable basis; and (c) there are adequate safeguards to insure that the opportunity of the public to enjoy these works will not be blocked by arbitrary fiat of either the performing right societies or collective groups of users.

If a tribunal should be set up to regulate rates of performing right societies, it is well to bear in mind the following observations made in the Report of the Copyright Committee of the British Board of Trade referred to above::00

${ }^{80}$ CMpD. No. 8662 , at 79 (No. 216). 
The constitution of a Tribunal of this kind is a matter of deep concern, since the powers it would exercise affect the community far more than is generally realised. In our view, the most appropriate Chairman of such a Tribunal would be a person who holds or has held high judicial office, if this is possible. But we realise the continual extraneous demands which are being made on the Judiciary and accordingly we make no definite recommendation in this sense. We are strongly of the opinion that the Chairman, if not a High Court Judge, should at any rate be a Barrister of standing, appointed by the Lord Chancellor. 